\title{
Evaluation of the Relationship Between COX-2 and Ki-67 Expression and Tumor Grade and Cox-2, Ki-67 Expression in Astrocytomas
}

\section{Astrositomalarda COX-2 ve Ki-67 Ekspresyonu ve Tümör Grade'i ile COX-2, Ki-67 Ekspresyonu Arasındaki İlişsinin Değerlendirilmesi}

\author{
Aysun Gökce ${ }^{1}$, Selda Seçkin ${ }^{2}$ \\ ${ }^{1}$ Sağlık Bilimleri Üniversitesi, Dışkapı Yıldırım Beyazıt Eğitim ve Araştırma Hastanesi, Tıbbi Patoloji, Ankara \\ ${ }^{2}$ Emekli, Tibbi Patoloji \\ Dergiye Ulaşma Tarihi: 19.01.2020 Dergiye Kabul Tarihi:11.02.2020 Doi: 10.5505/aot.2020.67299
}

\begin{abstract}
ÖZET
GİRIŞ ve AMAÇ: Bu çalışmada farklı grade'deki astrositomalarda COX-2 ve Ki-67 ekspresyonu incelendi. Bu iki belirteçin grade'ler arasındaki ekspresyon farklılığı ve birbiri ile olan ilişkisi değerlendirildi YÖNTEM ve GEREÇLER: Çalı̧̧maya retrospektif olarak 20 grade II, 20 grade III, 20 grade IV astrositoma tanısı almış toplam 60 operasyon materyali dahil edildi. İmmünhistokimyasal yöntemle Ki-67 ve COX-2 çalışıldı. Verilerin analizi SPSS for Windows 11.5 paket programında yapıldı. Shapiro Wilk testi, Mann Whitney U testi, Kruskal Wallis testi, çoklu karşılaştırma testi kullanıldı.

BULGULAR: Grade II'ye göre grade III ve IV astrositomalı olgularda COX-2 boyanma yaygınlığı daha yüksek olarak bulundu $(\mathrm{p}<0.001$ ve $\mathrm{p}<0.001)$. Grade III ile grade IV astrositomalı olgular arasinda COX-2 boyanma yaygınlığ açısından anlaml farklılık yoktu ( $\mathrm{p}=0.087)$. Grade II'ye ve grade III'e göre grade IV'te COX-2 ile kuvvetli boyanan olgu sayısı fazla idi $(\mathrm{p}<0.001 \mathrm{ve} p=0.030)$. Grade II ile grade III astrositomalı olgular arasında COX-2 boyanma yoğunluğu açısından anlamlı farklılık yoktu $(\mathrm{p}=0.198)$. Grade II'ye göre grade III ve grade IV tümörlerde ayrıca grade III'e göre grade IV tümörlerdeki Ki-67 indeksi daha yüksek olarak bulundu ( $\mathrm{p}=0.007$, $\mathrm{p}<0.001, \mathrm{p}<0.001)$. COX-2 boyanması olmayan gruba ve zayıf boyanan gruba göre kuvvetli boyanan grubun Ki67 indeksi daha yüksek olarak bulundu $(\mathrm{p}=0.004$ ve $\mathrm{p}=0.004)$. Boyanmayan ve zayıf boyanan grup arasında Ki67 indeksi benzerdi ( $\mathrm{p}=0.096)$.
\end{abstract}

TARTIŞMA ve SONUÇ: COX-2 ekspresyonunun astrositomaların progresyonunda rol oynayabileceği, daha agresif tümörleri yansıtabileceği, astrositomaların tedavisinde COX-2 inhibitörlerinin mevcut tedavi protokollerine ek terapötik role sahip olabileceği, farklı grade'e sahip tümörleri birbirinden ayırt etmede Ki67'nin kullanılabileceği düşünüldü.

Anahtar Kelimeler: Astrositoma, COX-2, Ki-67

ABSTRACT
INTRODUCTION: In the present study, COX-2 and Ki-67 expression were investigated in astrocytomas of different grade. Difference between the expressşon levels of these two markers and their relationship with each other were evaluated.

METHODS: A total of 60 surgical materials diagnosed as 20 grade II, 20 grade III, 20 grade IV astrocytoma retrospectively were included in the study. Ki-67 and COX-2 were studied by immunohistochemical method. Data analysis was performed using SPSS for Windows, version 11.5. Shapiro Wilk test, Mann Whitney U test, Kruskal Wallis test, and multiple comparison test were used.

RESULTS: The prevalence of COX-2 staining was higher in patients with grade III and IV astrocytoma than grade II $(\mathrm{p}<0.001$ and $\mathrm{p}<0.001)$. There was no significant difference between grade III and IV astrocytomas in terms of COX-2 staining prevalence $(\mathrm{p}=0.087)$. The number of cases stained with COX-2 in grade IV was higher than those of grade II and grade III ( $p<0.001$ and $p=0.030$ ). There was no significant difference between Grade II and Grade III astrocytomas in terms of COX-2 staining intensity $(\mathrm{p}=0.198)$.Ki-67 index was higher in grade III and grade IV tumors compared to grade II and in grade IV tumors compared to grade III $(p=0.007, p$ $<0.001, \mathrm{p}<0.001)$. The Ki-67 index of the strongly stained group was higher than the group without COX-2 staining and weak staining group $(\mathrm{p}=0.004$ and $\mathrm{p}=0.004)$. Ki-67 index was similar between unstained and poorly stained groups $(\mathrm{p}=0.096)$.

DISCUSSION AND CONCLUSION: We conclude that COX-2 expression may play a role in the progression of astrocytomas, may be associated with more aggressive gliomas, and COX-2 inhibitors may have a therapeutic role in addition to the existing treatment protocols of astrocytomas, and Ki-67 immunostaining might be effective in differentiating tumors of different grades. 


\section{GíRiş}

Beyin tümörlerinin insidans1 hafif olarak artmıştır ve prognoz özellikle yüksek grade'li neoplazilerde hala kötüdür (1). Gliomalar santral sinir sisteminin en sik görülen primer tümörleridir ve glial hücrelerden köken alan heterojen bir hastalık grubunu temsil ederler (2). Klinik ve patolojik kriterlerin baz alındığ 1 gliomalı hastalarda sağkalım süresini öngörmek güçtür (3). Histopatolojik grade'leme sistemindeki sınırlamalar sürekli yardımcı diagnostik ve prognostik belirteçler arama ile sonuçlanmıştır (4).

Siklooksijenaz (COX) araşidonik asitten prostaglandin sentezinde rolü olan bir enzimdir $(5,6)$. COX'un COX-1 ve COX-2 olmak üzere iki izoformu tanımlanmıştır. COX-1 ekspresyonu fizyolojik eikasonoid üretimi ile bağlantılıdır. COX-2 ekspresyonu ise karsinojenler, hormonlar, büyüme faktörleri, mitojenler, sitokinler, bakteriyal endotoksinler gibi çeşitli uyaranları takiben indüklenebilir (5-8). Güncel çalışmalar COX-2 ekspresyonundaki artışın kanserlerin gelişiminde rol oynayabileceğini ileri sürmüştür $(6,9)$.

Son zamanlarda astrositik tümörlerde siklooksijenaz-2 (COX-2) ekspresyonunu, farklı grade'deki tümörler arasındaki ekspresyon farklılı̆̆ını ve prognoz üzerine etkilerini değerlendiren çeşitli çalışmalar yapılmıştır (9-16). COX-2 ekspresyonundaki artış astrositomalar dışında baş-boyun, mide, pankreas, prostat, akciğer, over gibi çeşitli kanserlerde gösterilmiştir (17- 22). Mitotik indeks prolifere olan tümörlerin tespitini kolaylaştırır. Proliferatif belirteçler proliferatif fazdaki hücrelerin daha kesin değerlendirilmesini sağlarlar (3). Ki-67 büyüme fraksiyonunun hızlı, tekrarlanabilir bir şekilde değerlendirilmesine izin verir (23). Bugüne kadar astrositomalarda Ki-67 boyanma indeksi ile sağ kalım süresi ve farklı grade'e sahip tümörler arasındaki ekspresyon farklılıklarını değerlendiren çok sayıda çalışma yapılmıştır $(3,4,24-33)$.

\section{GEREÇ VE YÖNTEM}

$\mathrm{Bu}$ çalışmaya Ankara Numune Eğitim ve Araştırma Hastanesi Patoloji Bölümünde değerlendirilen WHO grade II astrositoma,
WHO grade III astrositoma, (anaplastik astositoma), WHO grade IV astrositoma, (glioblastoma) tanısı almış 20'şer olguya ait toplam 60 operasyon materyali dahil edildi. Klinik bulgular bölüm arşivi kayıtlarından ve rapor örneklerinden elde edildi. Her operasyon materyaline ait formalin fikse, parafine gömülü bloklardan hazırlanan hematoksilen-eozin boyalı lamlar yeniden incelendi. Tümörü en iyi temsil eden bloklar belirlendi. Seçilen her bloktan 3-4 mikron kalınlığında kesitler adezivli lamlara alındı. İmmünhistokimyasal yöntemle Ki-67 (clone MIB-1, DAKO) ve COX-2 (Neomarkers) çalışıldı. Pozitif kontrol olarak COX-2 için kolon adenokarsinomu olgularına ait kesitler, Ki-67 için ise tonsilden hazırlanan kesitler kullanıldı. COX-2 için sitoplazmik, Ki-67 için nükleer boyanma dikkate alındı. COX-2 için yapılan değerlendirmede semikantitatif olarak boyanan hücrelerin yaygınlığı ve boyanma yoğunluğu esas alındı. Buna göre boyanma yoğunluğu için 0: Boyanma yok, 1+: zayıf boyanma, 2+: Kuvvetli boyanma; boyanma yaygınlı̆̆ 1 için 1+: \%0-25 hücrede boyanma, 2+: \%26-50 hücrede boyanma, 3+: \%51-75 hücrede boyanma ve 4+: \%76-100 hücrede boyanma şeklinde skorlama yapıldı. Ki-67 için immünhistokimyasal çalışmada her olguda 1000 tümör hücresi üzerinden sayım yapıldı. Boyanan tümör hücre yüzdesi hesaplandı. Bu Ki-67 indeksi olarak değerlendirildi. Verilerin analizi SPSS for Windows 11.5 paket programında yapıldı. Sürekli değişkenlerin dağılımının normale uygun olup olmadığ Shapiro Wilk testi ile araştırıldı. Tanımlayıcı istatistikler sürekli yaş için ortalama \pm standart sapma, COX-2 yoğunluk, yaygınlık ve Ki-67 için ortanca (minimum- maksimum) olarak kategorik değişkenler ise vaka sayısı ve (\%) olarak gösterildi. Grade grupları arasında yaş ortalaması yönünden farkın önemliliği Tek Yönlü Varyans Analizi (One-Way ANOVA) ve beraberinde post hoc Tukey testi ile cinsiyet dağılımının benzer olup olmadığı ise Pearson'un Kikare testi ile değerlendirildi. Bağımsız gruplar arasında Ki-67 boyanma yüzdesi ortancaları yönünden farkın önemliliği ise bağımsı grup sayısı iki olduğunda Mann Whitney $U$ testi ile bağımsız grup sayısının ikiden fazla olduğu durumlarda ise Kruskal Wallis testi ile değerlendirildi. Grade grupları 
arasında COX-2 yoğunluk, yaygınlık düzeyleri yönünden farkın önemliliği de Kruskal Wallis testi ile değerlendirildi. Kruskal Wallis test istatistiği sonucunun önemli bulunduğu durumlarda anlamlı farka neden olan grupları tespit etmek amacıyla çoklu karşılaştırma testi yapıldı. Ki-67 boyanma yüzdesi ile yaş, COX2 yoğunluk, yaygınlık düzeyleri arasındaki doğrusal ilişkinin büyüklüğü Spearman'ın rho katsayısı ve önemlilik düzeyi hesaplanarak incelendi. Grade II'yi grade III ve IV'ten ayırt etmede Ki-67 boyanma yüzdesinin etkili olup olmadığ1 ROC eğrisi altında kalan alan hesaplanarak değerlendirildi. Eğri altında kalan alanın önemli bulunması halinde Ki-67 boyanma yüzdesine ilişkin en iyi kesim noktası Youden İndeks kullanılarak saptandı. Ayrıca, bu noktaya ilişkin duyarlılık, seçicilik, pozitif ve negatif tahmini değerler hesaplandi. $\mathrm{p}<0.05$ için sonuçlar istatistiksel olarak anlamlı kabul edildi.

\section{SONUÇLAR}

Çalışmamızda retrospektif olarak 20'si grade II, 20'si grade III, 20'si grade IV olmak üzere toplam 60 astrositoma olgusu değerlendirildi. Olguların 34'ü $(\% 56,7)$ erkek, 26's1 $(\% 43,3)$ kadındı. Yaş aralığı 2-75 arasında değişmekte idi.

Grade'ler arasında yaş ortalamaları yönünden istatistiksel olarak anlamlı farklılık saptand $1 \quad(p<0.001)$. Grade II ile grade III astrositoma olgularında yaş ortalamaları benzer iken ( $\mathrm{p}=0.558)$, Grade IV astrositomaların yaş ortalamas1 grade II ve grade III astrositomalara göre daha yüksek bulundu. Bu fark istatistiksel olarak anlamlı idi $(p<0.001$ ve $p<0.001)$.

Grade II, grade III, grade IV astrositomalı olgular arasında cinsiyet dağılımı istatistiksel olarak benzer bulundu $(\mathrm{p}=0.414)$ (Tablo 1).

$\mathrm{Bu}$ özelliklere sahip olgularda immünhistokimyasal olarak COX-2 ve Ki-67 çalış1ldı. Olguların 57'sinde (\%95) COX-2 ile boyanma izlendi. Tüm olgularda değişen oranlarda $(0,3-43,5)$ Ki-67 ile boyanma gözlendi.

COX-2 ile yapilan

immünhistokimyasal çalışmada COX-2 boyanma yaygınlığı ve yoğunluğu ayrı ayrı değerlendirildi. Tümör nekrozu çevresindeki alanlarda daha belirgin COX-2 ekspresyonu gözlendi. Ek olarak glomerüloid yapıdakileri de içeren bazı vasküler endotelyal hücrelerde, COX-2 pozitivitesi izlendi.

COX-2 yaygınlık skorları grade'e bağlı olarak anlamlı değişim göstermekte idi $(p<0.001)$. Grade II'ye göre grade III ve IV tümörlerde COX-2 yaygınlık skoru daha yüksek bulundu. $\mathrm{Bu}$ fark istatistiksel olarak anlamlı idi $(\mathrm{p}<0.001$ ve $\mathrm{p}<0.001)$. Grade III ile grade IV tümörler arasında COX-2 boyanma yaygınlığı açısından anlamlı farklılık yoktu $(\mathrm{p}=0.087)$ (Figür 1$)$.

COX-2 boyanma yoğunluğu grade'e bağlı olarak anlamlı değişim göstermekte idi $(p=0.003)$. Grade II'ye ve grade III'e göre grade IV tümörlerde $\mathrm{COX}-2$ boyanma yoğunluğu çoğu olguda kuvvetli olarak bulundu. $\mathrm{Bu}$ fark istatistiksel olarak anlamlı idi $(\mathrm{p}<0.001$ ve $\mathrm{p}=0.03)$. Grade II ile grade III tümörler arasında COX-2 boyanma yoğunluğu açısından anlamlı farklılık yok idi $(\mathrm{p}=0.198)$ (Tablo 2) (Figür 2).

Ki-67 boyanma indeksi grade II tümörlerde 0,3-16,3, grade III tümörlerde 140,7, grade IV tümörlerde 16,8-43,5 arasında değişmekte idi. Ki-67 boyanma düzeyi grade'e göre istatistiksel olarak anlamlı farkl1lık göstermekte idi $(p<0.001)$. Grade II'ye (ortanca 2,75) göre grade III (ortanca 10,1) ve grade IV tümörlerde (ortanca 28,1) Ki-67 boyanma düzeyi daha yüksek bulundu. Bu fark istatistiksel olarak anlaml idi $(\mathrm{p}=0.007$ ve $\mathrm{p}<0.001)$. Ayrica, grade III'e göre grade IV tümörlerdeki Ki-67 boyanma düzeyi de daha yüksek bulundu. Bu fark da istatistiksel olarak anlamlı idi $(\mathrm{p}<0.001)$ (Tablo 3) (Figür 3).

Farklı grade'e sahip tümörleri birbirinden ayırt etmede Ki-67'nin etkili olduğu ROC analizi ile görüldü. Grade II tümörlerin grade III ve grade IV tümörlerden ayrrt edilmesinde Ki-67'nin en iyi kesme noktasi 16.5 olarak, grade IV tümörleri grade III ve II tümörlerden ayırt etmede ise en iyi kesme noktası 20.5 olarak saptandı (Figür 4).

COX-2 yaygınlığ $1+$ olan grubun $\mathrm{Ki}$ 67 indeksi, 3+ olan grup, 2+ olan grup ve 1+ olan gruptan daha yüksek idi. 4+ yaygınlığa sahip olan grubun sirasiyla; $1+$ ve $3+$ olan gruba göre Ki-67 boyanma düzeyi arasındaki fark istatistiksel olarak anlamlı idi $(\mathrm{p}<0.001$ ve $\mathrm{p}=0.016)$. COX-2 yoğunluğu kuvvetli olan grubun Ki-67 indeksi, COX-2 yoğunluğu zayıf olan ve COX-2 ekspresyonu izlenmeyen gruptan daha yüksek idi. Bu fark istatistiksel olarak anlamlı idi ( $\mathrm{p}=0.004$ ve $\mathrm{p}=0.004)$. COX- 
2 ile boyanmayan ve zayif boyanan grup arasında Ki-67 boyanma düzeyleri benzerdi $(p=0.096)$. Yaş arttıkça Ki-67 boyanma yüzdesinde de istatistiksel olarak anlamlı artış görülmekte idi $(\mathrm{p}<0.01)$. Erkeklerde görülen Ki-67 indeksi kadınlarda görülen Ki-67 indeksinden daha yüksekti (Tablo 4).

Tablo1. Demografik Veriler

\begin{tabular}{|l|c|c|c|c|}
\hline $\begin{array}{l}\text { Değişke } \\
\text { nler }\end{array}$ & $\begin{array}{c}\text { Grade 2 } \\
\text { (n=20) }\end{array}$ & $\begin{array}{c}\text { Grade 3 } \\
\text { (n=20) }\end{array}$ & $\begin{array}{c}\text { Grade 4 } \\
\text { (n=20) }\end{array}$ & p \\
\hline Yaş (yıl) & $\begin{array}{c}35.8 \pm 12 \\
.3^{c}\end{array}$ & $\begin{array}{c}40.0 \pm 13 \\
.1^{\mathrm{d}}\end{array}$ & $\begin{array}{c}56.1 \pm 11 . \\
7^{\mathrm{c}, \mathrm{d}}\end{array}$ & $\begin{array}{c}<0.00 \\
1^{\mathrm{a}}\end{array}$ \\
\hline $\begin{array}{l}\text { Cinsiyet } \\
\text { E/K }\end{array}$ & $9 / 11$ & $12 / 8$ & $13 / 7$ & $\begin{array}{c}0.414 \\
\mathrm{~b}\end{array}$ \\
\hline
\end{tabular}

a Tek Yönlü Varyans Analizi

b Pearson Ki-Kare testi.

c Grade 2 ile Grade 4 arasındaki fark istatistiksel olarak anlamlı ( $p<0.001)$.

${ }^{d}$ Grade 3 ile Grade 4 arasındaki fark istatistiksel olarak anlamlı $(p<0.001)$.

Tablo 2. COX-2'nin Grade'e Göre Yaygınlık ve Yoğunluk Dağılımı

\begin{tabular}{|c|c|c|c|}
\hline Değişkenler & $\begin{array}{c}\text { Grade } \\
2 \\
(\mathrm{n}=20)\end{array}$ & $\begin{array}{c}\text { Grade } \\
3 \\
(\mathrm{n}=20)\end{array}$ & $\begin{array}{c}\text { Grade } \\
4 \\
(n=20)\end{array}$ \\
\hline \\
\hline $\begin{array}{c}\text { Yayginlık } \\
1+\end{array}$ & $\begin{array}{c}17 \\
0\end{array}$ & $\begin{array}{c}3 \\
(07150)\end{array}$ & $\begin{array}{c}1 \\
(0150)\end{array}$ \\
\hline $2+$ & $\begin{array}{c}3 \\
3 \\
(\% 15.0)\end{array}$ & $\begin{array}{c}1 \\
(\% 5.0)\end{array}$ & - \\
\hline $3+$ & - & $\begin{array}{c}4 \\
(\% 20.0)\end{array}$ & - \\
\hline $4+$ & - & $\begin{array}{c}12 \\
(\% 60.0)\end{array}$ & $\begin{array}{c}19 \\
(\% 95.0)\end{array}$ \\
\hline \multicolumn{4}{|l|}{$\begin{array}{l}\text { COX } 2 \\
\text { Yos̆unluk }\end{array}$} \\
\hline Yok & $\begin{array}{c}3 \\
(\% 15.0)\end{array}$ & - & - \\
\hline Zaylf & $\begin{array}{c}14 \\
(\% 70.0)\end{array}$ & $\begin{array}{c}15 \\
(\% 75.0)\end{array}$ & $\begin{array}{c}8 \\
(\% 40.0)\end{array}$ \\
\hline Güçlü & $\begin{array}{c}3 \\
(\% 15.0)\end{array}$ & $\begin{array}{c}5 \\
(\% 25.0)\end{array}$ & $\begin{array}{c}12 \\
(\% 60.0)\end{array}$ \\
\hline
\end{tabular}

Tablo3. Grade'e Göre Cox 2'nin Yaygınlık, Yoğunluk ve Ki-67 Düzeyleri

\begin{tabular}{|l|l|l|l|l|}
\hline Değişkenler & $\begin{array}{l}\text { Grade } \\
\mathbf{2} \\
(\mathbf{n = 2 0})\end{array}$ & $\begin{array}{l}\text { Grade } \\
\mathbf{3} \\
(\mathbf{n}=\mathbf{2 0})\end{array}$ & $\begin{array}{l}\text { Grade } \\
\mathbf{4} \\
(\mathbf{n}=\mathbf{2 0})\end{array}$ & $\mathbf{p}^{\mathrm{a}}$ \\
\hline Cox 2 & $1(1-$ & $4(1-$ & $4(1-$ & $<0.001$ \\
Yoğunluk & $2)^{\mathrm{b}, \mathrm{c}}$ & $4)^{\mathrm{b}}$ & $4)^{\mathrm{c}}$ & \\
\hline Cox 2 & $1(0-$ & $1(1-$ & $2(0-$ & 0.003 \\
\hline
\end{tabular}

\begin{tabular}{|l|l|l|l|l|} 
Yayginlık & $2)^{\mathrm{c}}$ & $2)^{\mathrm{d}}$ & $2)^{\mathrm{c}, \mathrm{d}}$ & \\
\hline Ki-67 & 2.75 & 10.1 & 28.1 & $<0.001$ \\
& $(0.3-$ & $(1.0-$ & $(16.8-$ & \\
& $16.3)^{\mathrm{b}, \mathrm{c}}$ & $40.7)^{\mathrm{b}, \mathrm{d}}$ & $43.5)^{\mathrm{c,d}}$ & \\
\hline
\end{tabular}

${ }^{\text {a }}$ Kruskal Wallis testi.

${ }^{\mathrm{b}}$ Grade 2 ile Grade 3 arasındaki fark istatistiksel olarak anlamli $(\mathrm{p}<0.01)$

${ }^{c}$ Grade 2 ile Grade 4 arasındaki fark istatistiksel olarak anlamlı $(\mathrm{p}<0.001)$

${ }^{\mathrm{d}}$ Grade 3 ile Grade 4 arasındaki fark istatistiksel olarak anlamlı $(\mathrm{p}<0.05)$

Tablo 5. Cinsiyet, COX-2 Yayginlık ve Yoğunluğuna Göre Ki-67 Boyanma Yüzdesi

\begin{tabular}{|l|c|c|}
\hline Değişkenler & $\begin{array}{c}\text { Ki-67 } \\
\text { Ortanca (Min.- } \\
\text { Maks.) }\end{array}$ & p \\
\hline $\begin{array}{c}\text { Cinsiyet } \\
\text { Erkek }\end{array}$ & $16.1(0.3-43.5)$ & $0.765^{\mathrm{a}}$ \\
Kadın & $10.0(1.1-40.7)$ & \\
\hline COX-2 & & $0.002^{\mathrm{b}}$ \\
Yaygınlık & $3.8(0.3-40.7)^{\mathrm{c}}$ & \\
$1+$ & $5.4(1.7-30.5)$ & \\
$2+$ & $6.3(1.0-19.3)^{\mathrm{d}}$ & \\
$3+$ & $22.8(1.2-43.5)^{\mathrm{c}, \mathrm{d}}$ & \\
$4+$ & & $0.010^{\mathrm{b}}$ \\
\hline COX-2 & & \\
Yoğunluk & $2.6(0.4-6.6)^{\mathrm{e}}$ & \\
Yok & $8.2(0.3-43.5)^{\mathrm{f}}$ & \\
Zayıf & $22.5(3.2-43.2)^{\mathrm{e}, \mathrm{f}}$ & \\
Güçlü & & \\
\hline
\end{tabular}

${ }^{a}$ Mann Whitney U testi.

${ }^{\mathrm{b}}$ Kruskal Wallis testi.

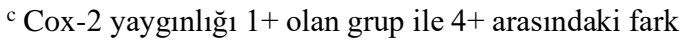
istatistiksel olarak anlamlı $(\mathrm{p}<0.001)$

${ }^{\mathrm{d}}$ Cox-2 yaygınlığ $3+$ olan grup ile $4+$ arasındaki fark istatistiksel olarak anlamlı $(\mathrm{p}=0.016)$

${ }^{\mathrm{e}} \mathrm{Cox}-2$ yoğunluğu olmayan grup ile güçlü olan grup arasındaki fark istatistiksel olarak anlamlı $(\mathrm{p}=0.004)$ ${ }^{\mathrm{f}} \mathrm{Cox}-2$ yoğunluğu zayıf olan grup ile güçlü olan grup arasındaki fark istatistiksel olarak anlamlı $(\mathrm{p}=0.004)$

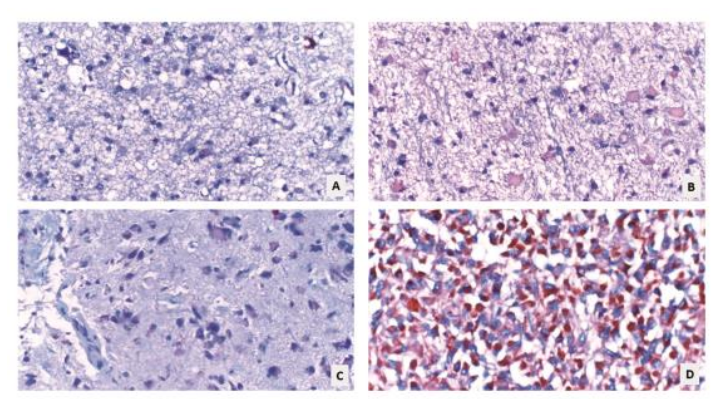

Figür 1.A: Grade II astrositomada COX-2 ile $1+$ boyanma yaygınlı $\mathrm{g} 1$ (x200), B: Grade II astrositomada COX-2 ile $2+$ boyanma yaygınlığı $(x 200)$, C: Grade III astrositomada COX-2 ile $3+$ boyanma yaygınlığ 1 (x200), D: Grade IV astrositomada COX-2 ile 4+ boyanma yaygınlığı (x200)

Adress for correspondence: Uzm. Dr. Aysun Gökce Ziraat Mh., Şht. Ömer Halisdemir Blv, Dışkapı - Altındağ 06610 Ankara - Türkiye

e-mail: aysungokce80@yahoo.com.tr

Available at www.actaoncologicaturcica.com

Copyright $\mathbb{C}$ Ankara Onkoloji Hastanesi 


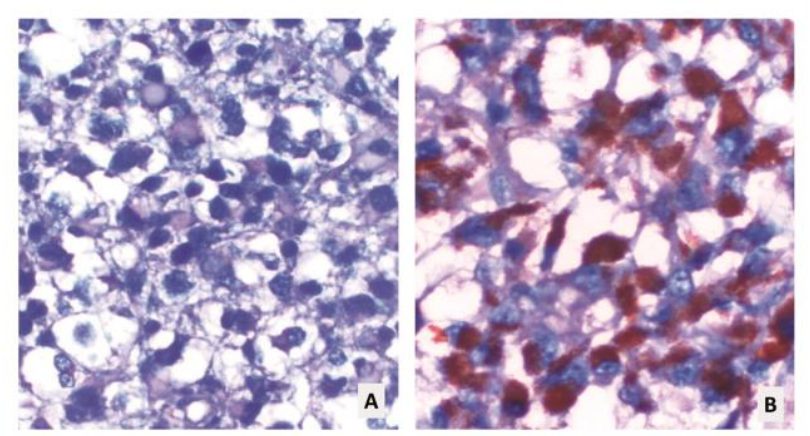

Figür 2.A: Grade III astrositomada COX-2 ile zayıf boyanma (x400), B: Grade IV astrositomadaki COX-2 ile kuvvetli boyanma (x400)
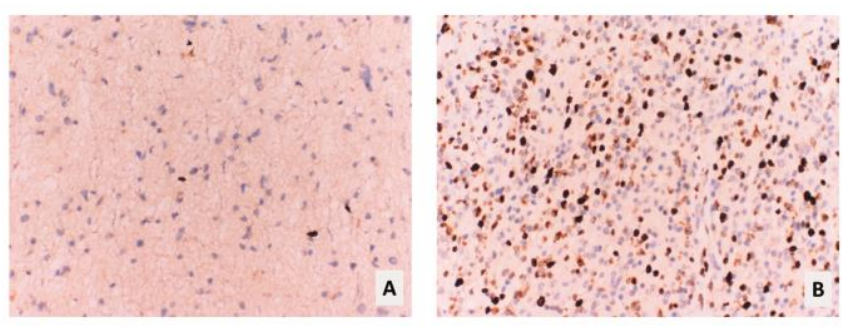

Figür 3.A: Grade II astrositomada düşük Ki67 immünreaktivitesi (x200), B: Grade IV astrositomada $\mathrm{Ki}-67$ ile yaygın nükleer ekspresyon (x200)

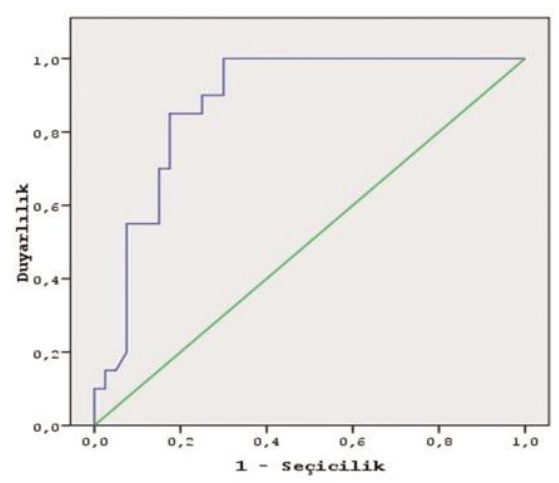

Figür 4: ROC eğrisi

\section{TARTIŞMA}

Astrositomalarda tek başına grade baz alındığında hastaların klinik gidişini saptamak mümkün değildir. Çünkü aynı grade'deki astrositomalar farklı davranabilirler (32).

Çalışmamıza dahil ettiğimiz toplam 60 olgudan 34'ü $(\% 56,7)$ erkek, 26's1 $(\% 43,3)$ kadındı. Beyin tümörlerinin erkeklerde biraz daha fazla görülme eğiliminde olduğu bilinmektedir. Olgulardaki yaş aralığı 2-75 arasında değişmekteydi. Grade II ile grade III astrositomalı olgularda yaş ortalamaları benzer iken $(p=0.558)$, grade IV astrositomal olguların yaş ortalaması grade II ve grade III astrositomalı olgulara göre daha yüksek olarak bulundu. Bu fark istatistiksel olarak anlamlı idi $(\mathrm{p}<0.001$ ve $\mathrm{p}<0.001)$. Glioblastomal1 olguların grade II ve grade III olgulara göre daha ileri yaşta görülme eğilimleri olduğu bilinmektedir.

Çalışmamızda grade II'li olguların 17'sinde, grade III ve IV'lü olguların tamamında COX-2 ile boyanma gözlendi (\%95). Astrositik tümörlerde raporlanan COX2 immünreaktivitesinin sıklı̆ $1 \% 55$ ile $\% 100$ - arasında değişmektedir $(12,34)$. Çalışmamızda elde ettiğimiz oran (\%95) Perdiki ve arkadaşları (ark.).nın sonuçları ile aynı (\%95) idi ve Joki ve ark.nın çalışma sonuçları ile çok benzerdi $(\% 94)(13,16)$.

Biriken kanitlar ile kanserlerin gelişiminde COX-2 yolu ile PG seviyelerindeki artışın önemli olduğu düşünülmektedir (35). Gliomaların progresyon ve formasyonunda COX-2 ve PG'lerin önemi ve tümör grade'i ile artmış PG sentezi arasında korelasyonlar ve gliomalar içinde $P G$ seviyelerinde artış tanımlanmıştır (36).

$\mathrm{Bu}$ çalışmada grade II'ye göre grade III ve IV astrositomal olgularda COX-2 yaygınlık skoru daha yüksek olarak bulundu. $(p<0.001$ ve $p<0.001)$. Grade III ile grade IV astrositomalı olgular arasinda COX-2 boyanma yaygınlığı açısından anlamlı farklılık yoktu $(p=0.087)$. Lee ve ark., Shono ve ark. yaptıkları çalışmada COX-2 ekspresyon oranı ile hasta sağkalım süresi ve tümörün patolojik grade'i korele bulunmuştur $(11,12)$. Perdiki ve ark. ve El-Sayed grade IV astrositomalarda grade II ve grade III astrositomalardan daha yüksek COX-2 ekspresyonu gözlemiştir $(9,13)$. Joki ve ark.nın çalışmasında da COX-2 yaygınlığ 1 grade ile korele olarak bulunmuştur (16). Zhang F ve ark. grade I-II ile kıyaslandığında grade III-IV olgularda daha yükssek COX-2 ekspresyonu saptamıştır (10).

$\mathrm{Bu}$ çalı̧̧mada COX-2 boyanma yoğunluğu grade'e bağlı olarak anlamlı değişim göstermekte idi $(p=0.003)$. Joki ve ark.nın çalışmasında 15 grade II astrositomanın tamamında zayıf boyanma gözlenirken 10 grade III astrositomanın 9'unda, 25 grade IV 
astrositomanın 16'sinda COX-2 ile kuvvetli boyanma elde edilmiştir (16). Yüksek grade'li tümörlerde daha yaygin ve daha yoğun COX-2 ekspresyonu izlenmesi nedeniyle astrositomalarda tümör progresyonununda COX-2'nin önemli rol oynayabileceği ve COX-2 ekspresyonunun daha agresif tümörleri yansitabileceği düşüncesi oluşmuştur.

Diğer organlarda COX-2 ile yapılan çalışmalarda değişik sonuçlar elde edilmiştir. Sung ve ark.nın yaptığı çalışmada kronik aktif gastrit, atrofik gastrit, intestinal metaplazi ve mide adenokarsinomu olguları arasında COX-2 ekspresyonu açısından korelasyon bulunamamıştır (37) . Okami ve ark. pankreatik benign kistadenomalarda zayıf, pankreatik karsinomalarda ise kuvvetli COX-2 pozitivitesi izlemiştir (38). Yoshimura ve ark. benign prostat hipertrofisinde zayıf COX-2 ekspresyonu izlerken, prostat karsinomunda belirgin boyanma gözlemişlerdir (39).

Çalışmamızdaki COX-2 pozitif tümör hücreleri tümör dokusunda dağınık olarak izlenmekte idi. Bununla birlikte, tümör nekrozu çevresindeki alanlarda daha belirgin COX-2 ekspresyonu gözlendi. Çeşitli çalışmalarda bizim çalışmamızdakine benzer şekilde tümör nekrozu çevresindeki alanlarda belirgin COX-2 ekspresyonu olduğu raporlanmıştır $(12,13,15,34)$. Joki ve ark. ise tümör nekrozu çevresindeki alanlarda COX-2 ekspresyonunda belirginleşme gözlememiştir (16). Çalışmamızda gözlediğimiz tümör nekrozu çevresindeki alanlar da daha belirgin COX-2 ekspresyonu, iskemi ve travmada olduğu gibi hipoksi ya da hipoglisemi tarafindan COX-2'nin indüklendiğini gösteriyor olabilir. Bununla beraber, nekroz bulunmayan alanlarda da COX-2 boyanmasının gözlenmesi, COX-2'nin esas olarak tümör hücreleri tarafindan eksprese ediliyor olabileceğini akla getirmektedir.

Çalı̧̧mamızda

glomerüloid

yapıdakileri de içeren bazı vasküler endotelyal hücrelerde COX-2 pozitivitesi izlendi. Astrositomalarda COX-2 ile yapılan baz1 çalışmalarda endotelyal hücrelerde COX-2 pozitivitesi izlenmiştir $(12,13,14,15,16)$. Anjiogenezis çoğu neoplazmın gelişim, progresyon ve metastazında esas komponenttir. Tümör anjiogenik peptitler sekrete eder ve bunlar tümör neovaskülarizasyonuna katkıda bulunur. Neovaskülarizasyon ise tümör büyümesi için gerekli kanı sağlar (3).
Anjiogenezis, astrositik gliomaların gelişiminde neovaskülarizasyonu indükleyen ve inhibe eden çeşitli moleküller arasındaki dengeye bağımlı olarak anahtar rol oynar. Astrositik gliomaların büyümesi için öncesinde neoangiogenezis gereklidir. Vasküler proliferasyon ve tümörün agresifliği arasında korelasyon tanımlanmıştır. Anjiogenezis çok kompleks ve çok basamaklı bir durumdur (14). Bir çalışmada COX-2 ekspresyonu güçlü bir şekilde INOS, VEGF ve yüksek MVD ile bağlantılı bulunmuştur. Tek değişkenli analizlerde COX-2 ekspresyonu ve kötü gidiş arasında önemli bağlantı gösterilmiştir. COX-2 ve VEGF bağlantılı anjiogenezis için elde edilen bu bulgular COX-2 yolunun yeni damar yapısinı destekleyerek astrositik tümörigenezise katkıda bulunabileceği düşüncesine sebep olmuştur (14). Diğer bir çalışmada da COX-2, VEGF ve MVD arasında pozitif korelasyon bulunmuştur (9). Bizim çalışmamızda hiperplastik endotelyal hücrelerde COX-2 ile boyanma olması, angiogeneziste COX-2'nin rol oynayabileceğini düşündürmüştür.

14 primer ve 14 rekürren glioblastoma olgusunun dahil edildiği bir çalışmada immünhistokimyasal olarak COX-2 ve EGFR çalışılmış ve aynı hastanın primer tümörü ve rekürrensi arasında COX-2 ekspresyonu açısından korelasyon bulunamamıştır. Fakat daha yüksek COX-2 ekspresyonu olanlarda daha erken rekürrens görülebildiği saptanmıştır. COX-2 ekspresyonu ve sağkalım süresi arasında korelasyon gösterilememiştir (15). Başka çalışmalarda da COX-2 ekspresyon oran1 yüksek olan olgularda sağkalım süresi daha kısa olarak bulunmuştur. Tümör hücrelerindeki yüksek $\mathrm{COX}-2$ ekspresyonu klinik olarak daha agresif gliomalar ile ilişkilidir ve kötü prognozu gösterir sonucuna ulaşmışlardır $(10,11)$. Shono ve ark. glioblastomalı olgularda radyoterapiyi takiben $\mathrm{COX}-2$ pozitif tümör hücreleri \%50-100 arasında olanların pozitif tümör hücreleri \%0-50 arasında olanlardan daha kısa sağkalım süresine sahip olduklarını göstermiştir. COX-2 ekspresyonunun olguların gidişatının tespitinde güçlü bir gösterge olduğu sonucuna ulaşılmıştır (12). Buccoliera ve ark.nın oligodendrogliomalarda yaptığı bir çalışmada, yüksek grade'li olanlarda düşük grade'lilerden daha yüksek COX-2 ekspresyonu izlenmiştir. COX-2 negatif 
olguların, COX-2 pozitif olanlardan daha uzun sağkalım süresine sahip oldukları gözlenmiştir. COX-2 overekspresyonunun prognostik önemi muhtemel olarak bu enzimin tümör büyüme ve progresyonunu stimüle etme kapasitesine dayanır (40). Bizim çalışmamızda yüksek grade'li olgularda düşük grade'li olgulardan daha yüksek COX-2 ekspresyonu izlendi. Grade arttıkça prognozun kötüleştiği göz önüne alınırsa yüksek COX-2 ekspresyonunun kötü prognuzu gösterdiği düşünülebilir.

COX-2'nin nas1 bir mekanizma ile kanser gelişimine katkıda bulunduğu hala açık değildir. Biyolojik ve klinik kanıtlar ile COX2'nin tümör ile ilişkili birkaç proçeste moleküler seviyelerde işin içine karıştığ 1 düşünülmektedir. Tümör süpresör gen olan p53 çoğu kanserde inaktivedir ya da mutasyona uğramıştır. p53 aynı zamanda COX-2 ekspresyonunu inhibe edebilir. Mutant p53 COX-2 seviyelerini azaltamaz (41). p53 mutasyonu yükssek grade'li gliomalarda düşük grade'li gliomalardan daha s1k gözlenir (13). p53 ve COX-2 arasındaki bağlantıyı açığa çıkarmak, tümör grade'indeki artış ile COX-2 seviyelerinde niçin artma olduğunu anlamada önemli olabilir.

Selektif COX-2 inhibisyonu glioma hücrelerinde apoptozisi indükler ve proliferasyonu azaltır $(13,42)$. Joki ve ark. bir COX-2 inhibitörü olan NS-398 ile insan glioma hücrelerinde apoptoziste artış, proliferasyon ve invazyonda azalma olduğunu gözlemişlerdir (16). Artmış COX-2 ekspresyonu, antiapoptotik protein olan bcl2'nin miktarındaki artış ile ilişkilidir (43). Rat intestinal epitel hücrelerinde artmış COX-2 ekspresyonu ile bu hücrelerde apoptoz eğiliminde azalma olduğu yönünde bilgi mevcuttur (12). Sato A ve ark.nın bir çalışmasında COX-2 blokajının apopitozisi indüklediği bulunmuştur (42). COX-2 normal dokularda ya hiç ekprese olmaz yada çok az eksprese olur iken malign dokularda ekpresyonunun arttığının bulunmasından beri, COX-2 bağlantılı yollar terapötik yaklaşımlar için potansiyel hedef olarak tanımlanmıştır (15).

Çalışmamızda grade arttıkça astrositomalardaki Ki-67 boyanma indeksinde artma olduğu gözlenmiştir. Daha önce yapılan çalışmalarda da bizim çalışmamızdakine benzer şekilde astrositomalardaki Ki-67 boyanma indeksinin grade arttıkça artma eğiliminde olduğu gözlenmiştir $(3,4,26,27,28,30,33,44,45,46)$. Bu sonuçlara göre grade ile Ki-67 indeksindeki artış, daha kötü seyirli hastalık ile bağlantılı gözükmektedir.

Çalışmaların bazılarında grade II astrositoma ile grade III astrositoma ve grade II astrositoma ile grade IV astrositoma arasinda istatistiksel olarak anlamlı farklılık bulunurken grade III astrositoma ile grade IV astrositoma arasındaki ayrımda farklılık gözlenmemiştir $(3,26,27,28,45,46)$. Bazı araştırmalarda ise bizim çalışmamıza benzer şekilde düşük ve yüksek grade'liler yanısıra grade III astrositoma ve grade IV astrositoma arasinda da Ki-67 indeksi açısından istatistiksel olarak anlamlı farkl1lıklar gözlenmiştir $(33,44,47)$. Bu sonuçlar özellikle küçük biyopsilerde Ki-67 indeksinin histopatolojik, radyolojik ve klinik bulgulara ek tanısal yardımcı metod olarak kullanılabileğini düşündürmüştür. Prognostik faktör olarak Ki-67 indeksini değerlendiren çalışmalarda belirlenen 'cut-off' değerleri oldukça değişkendir. Hsu ve ark.nın yapmış olduğu çalışmada Ki-67 indeksi $>1,5$ bulunanlar daha kötü prognoz ile bağlantılı iken, Schiffer ve ark.nın çalışmasında Ki-67 indeksi $>8$ olanlar daha kisa survival ile bağlantılı olarak bulunmuştur (26,31). Bir başka çalışmada ise prognostik değer için 'cutoff' noktası 2,8 olarak bulunmuştur (45). Sallinen ve ark.nın yapmış olduğu çalışmada $\mathrm{Ki}-67$ indeksi açısından grade II ile grade III tümörler arasında istatistiksel olarak anlamlı farklılıklar elde edilmiştir. En iyi sensitivite ve spesifiteye Ki-67 indeksi için 'cut-off' değerinin 8 olduğu durumda ulaşılmıştır. Prognostik değer için 'cut-off' noktası ise 15,3 olarak değerlendirilmiştir (48). Bizim çalışmamızda grade II tümörlerin grade III ve grade IV tümörlerden ayırt edilmesinde Ki67'nin en iyi kesme noktasi 16.5 olarak bulundu. Grade IV tümörleri indeksi açısından 16,5 'un altındaki değere sahip olgular $\% 100$ seçicilik \%40 duyarlılık oranında grade II tanısı almaktadır. Ki-67 indeksi açısından 20,5 'un üzerindeki değere sahip olgular ise $\% 95$ duyarlılık, \%75 seçicilik oranında grade IV tanisı almaktadir.

Astrositomalarda Ki-67 indeksini değerlendiren çalışmalarda grade'ler için bulunan ortalama ve ortanca değerler oldukça değişkendir. Hsu ve ark.nın 16 grade II astrositoma, 31 grade III astrositoma, 33 grade 
IV astrositoma olgusunu içeren çalıșmasında ortalama Ki-67 değerleri sırasılyla; 0.88, 8,75, 9,12 olarak gözlenmiştir (26). Eneström ve ark.nın 6 grade II astrositoma, 9 grade III astrositoma, 7 grade IV astrositoma olgusunda yapmış olduğu bir çalışmada ise ortalama $\mathrm{Ki}$ 67 değerleri sirasıyla; 7.6, 13.3, 24.3 olarak izlenmiştir (44). Yani bir çalışmada grade IV astrositoma için gösterilen değer başka bir çalışmadaki grade II astrositomada saptanan değer ile aynı olabilir. Bu da Ki-67 indeksinin tek başına tanı koymada yeri olmadığını, ancak diğer histopatolojik, klinik, radyolojik bulgular ile beraber değerlendirildiğinde anlamlı sonuçlara ulaşılabileceğini göstermektedir. Gerek diagnostik gerek prognostik amaçl1 belirlenen ortalama Ki-67 düzeyleri oldukça değişkenlik göstermektedir. Yapılan çalışmalar arasında ve hatta aynı tümördeki farklı örneklerde bile ortalama Ki-67 indeksini saptamak hala problemdir. Bu durum, Ki-67 indeksi için standardizasyon kurulmak istenmesine rağmen laboratuarlar arasındaki farklılı̆̆ 1 yansitıyor olabilir. Bu değişkenlik immünhistokimyasal prosedür ve immün boyamanın yorumundaki farklıliklar, doku seçimi ve tümörün heterojenliğine de bağlı olabilir. Çalışmamızda COX-2 boyanma yaygınlığ1 ve yoğunluğu arttıkça Ki-67 boyanma yüzdesinde de istatistiksel olarak anlamlı artış görülmekte idi. Shono ve ark.nın yapmış olduğu çalışmada yüksek COX-2 ekspresyonu artmış histolojik grade ile korele olarak bulunur iken, p53 immün boyanmas1, bcl-2 ekspresyonu, retinoblastoma $(\mathrm{Rb})$ protein ekspresyonu, p16 kayb1 ve yüksek MIB-1 ekspresyonu ile korele bulunmamıştır (12). Perdiki ve ark. ise COX-2 ekspresyonundaki artış ile histolojik grade, proliferatif potansiyel ve bu tümörlerde anjiogenezisi yönlendirdiği bilinen VEGF, anjiogenik faktör HIF-1 $\alpha$ ekspresyonu ve vasküler yüzey alanı ile yakın ilişsi saptamışlardır (13). Prayson ve ark. 47 glioblastoma olgusunda immünhistokimyasal olarak MIB1 ve COX-2 boyanmasi arasındaki korelasyonu değerlendirmiş ve daha yüksek hücre proliferasyon oranına sahip tümörlerin, COX-2 ekspresyonunda artma eğilimi olduğunu göstermiştir (49). Bu çalışmada da Perdiki ve ark. ve Prayson ve ark.nın çalışmasındakine benzer şekilde COX-2 ekspresyonu ve Ki-67 indeksi ilişkili bulunmuştur. Proliferatif aktivitede artış ile COX-2 ekspresyonundaki artış korele olarak değerlendirilmiştir. $\mathrm{Bu}$ durum $\mathrm{COX}-2$ ekspresyonundaki artışın astrositomaların proliferasyonunda rol oynayabileceğini ya da proliferatif aktivitenin COX-2 ekspresyonunda artışa neden olabileceğini düşündürmüştür.

$\mathrm{Bu}$ çalışmada yaş arttıkça Ki-67 boyanma yüzdesinde de istatistiksel olarak anlamlı artış görülmekte idi. Astrositomalı olgularda, herhangi bir histolojik grade'e sahip olguda yaş ile sağ kalım ters orantılıdır. Bu sebeple yaş arttıkça tümörlerdeki proliferatif potansiyelin bir göstergesi olan Ki-67 indeksinde de artış olabilir

\section{SONUÇ}

Sonuçlar yüksek COX-2 ekspresyonunun astrositomalarin progresyonunda, proliferasyonunda rol oynayabileceğini, daha agresif tümörleri yansitabileceğini, astrositomalarm tedavisinde COX-2 inhibitörlerinin mevcut tedavi protokollerine ek olarak potansiyel bir terapötik role sahip olabileceğini düşündürdü.

Ayrıca farklı grade'e sahip tümörler arasında, Ki-67 indeksi açısından anlamlı farklılıklar olması nedeni ile özellikle küçük biyopsilerde tümörler değerlendirilirken $\mathrm{Ki}-67$ indeksinin ek tanısal yöntem olabileceği düşünülmüştür. Ki-67 indeksindeki artış, daha kötü seyirli hastalık ile de bağlantılı gözükmektedir.

\section{REFERANSLAR}

1. Gholamrezanezhad A, Shooli H, Jokar N, Nemati R, Assadi M. Radioimmunotherapy (RIT) in Brain Tumors. Nucl Med Mol Imaging 2019; 53(6): 374-81.

2. Pessoa IA, Amorim CK, Ferreira WAS, et al. Detection and Correlation of Single and Concomitant TP53, PTEN, and CDKN2A Alterations in Gliomas. Int J Mol Sci 2019; 20(11).

3. McKeever PE, Ross DA, Strawderman MS, Brunberg JA, Greenberg HS, Junck L. A comparison of the predictive power for survival in gliomas provided by MIB-1, bromodeoxyuridine and proliferating cell nuclear antigen with histopathologic and clinical parameters. J Neuropathol Exp Neurol 1997; 56(7): 798-805.

4. Johannessen AL, Torp SH. The clinical value of Ki-67/MIB-1 labeling index in human astrocytomas. Pathol Oncol Res 2006; 12(3): 143-7. 
5. Dubois RN, Abramson SB, Crofford L, et al. Cyclooxygenase in biology and disease. Faseb $\mathrm{j}$ 1998; 12(12): 1063-73.

6. Taketo MM. Cyclooxygenase-2 inhibitors in tumorigenesis (part I). J Natl Cancer Inst 1998; 90(20): 1529-36.

7. DuBois RN, Awad J, Morrow J, Roberts LJ, 2nd, Bishop PR. Regulation of eicosanoid production and mitogenesis in rat intestinal epithelial cells by transforming growth factoralpha and phorbol ester. J Clin Invest 1994; 93(2): 493-8

8. Smith WL, Garavito RM, DeWitt DL. Prostaglandin endoperoxide $\mathrm{H}$ synthases (cyclooxygenases)-1 and -2. J Biol Chem 1996; 271(52): 33157-60.

9. $\quad$ El-Sayed M, Taha MM. Immunohistochemical expression of cycloxygenase-2 in astrocytoma: correlation with angiogenesis, tumor progression and survival. Turk Neurosurg 2011; 21(1): 27-35.

10. Zhang F, Chu J, Wang F. Expression and clinical significance of cyclooxygenase 2 and survivin in human gliomas. Oncol Lett 2017; 14(2): 1303-8.

11. Lee JM JS, Rhu HH, Kim IY, Lee MC. Cyclooxygenase-2 Expression Predicts Prognosis in Astrocytic Tumors. J Korean Neurosurg Soc 2004; 36: 437-42..

12. Shono T, Tofilon PJ, Bruner JM, Owolabi O, Lang FF. Cyclooxygenase-2 expression in human gliomas: prognostic significance and molecular correlations. Cancer Res 2001; 61(11): 4375-81.

13. Perdiki M, Korkolopoulou P, Thymara I, et al. Cyclooxygenase-2 expression in astrocytomas. Relationship with microvascular parameters, angiogenic factors expression and survival. Mol Cell Biochem 2007; 295(1-2): 75-83.

14. Hara A, Okayasu I. Cyclooxygenase-2 and inducible nitric oxide synthase expression in human astrocytic gliomas: correlation with angiogenesis and prognostic significance. Acta Neuropathol 2004; 108(1): 43-8.

15. Sminia P, Stoter TR, van der Valk P, et al. Expression of cyclooxygenase- 2 and epidermal growth factor receptor in primary and recurrent glioblastoma multiforme. J Cancer Res Clin Oncol 2005; 131(10): 653-61.

16. Joki T, Heese O, Nikas DC, et al. Expression of cyclooxygenase 2 (COX-2) in human glioma and in vitro inhibition by a specific COX-2 inhibitor, NS-398. Cancer Res 2000; 60(17): 4926-31.

17. Zweifel BS, Davis TW, Ornberg RL, Masferrer JL. Direct evidence for a role of cyclooxygenase 2-derived prostaglandin E2 in human head and neck xenograft tumors. Cancer Res 2002; 62(22): 6706-11.

18. Buskens CJ, Sivula A, van Rees BP, et al. Comparison of cyclooxygenase 2 expression in adenocarcinomas of the gastric cardia and distal oesophagus. Gut 2003; 52(12): 1678-83.

19. Molina MA, Sitja-Arnau M, Lemoine MG, Frazier ML, Sinicrope FA. Increased cyclooxygenase-2 expression in human pancreatic carcinomas and cell lines: growth inhibition by nonsteroidal anti-inflammatory drugs. Cancer Res 1999; 59(17): 4356-62.

20. Liu XH, Yao S, Kirschenbaum A, Levine AC. NS398, a selective cyclooxygenase-2 inhibitor, induces apoptosis and down-regulates bcl-2 expression in LNCaP cells. Cancer Res 1998; 58(19): 4245-9.

21. Brown JR, DuBois RN. Cyclooxygenase as a target in lung cancer. Clin Cancer Res 2004; 10(12 Pt 2): 4266s-9s.

22. Erkinheimo TL, Lassus H, Sivula A, et al. Cytoplasmic HuR expression correlates with poor outcome and with cyclooxygenase 2 expression in serous ovarian carcinoma. Cancer Res 2003; 63(22): 7591-4.

23. Key G, Becker MH, Baron B, et al. New Ki-67equivalent murine monoclonal antibodies (MIB 1-3) generated against bacterially expressed parts of the Ki-67 cDNA containing three 62 base pair repetitive elements encoding for the Ki-67 epitope. Lab Invest 1993; 68(6): 629-36.

24. Alimohammadi E, Bagheri SR, Sadeghsalehi A, Rizevandi P, Rezaie Z, Abdi A. Prognostic factors in patients with glioblastoma multiforme: focus on the pathologic variants. Acta Neurol Belg 2019.

25. Ahmadipour Y, Jabbarli R, Gembruch O, et al. Impact of Multifocality and Molecular Markers on Survival of Glioblastoma. World Neurosurg 2019; 122: e461-e6.

26. Hsu DW, Louis DN, Efird JT, Hedley-Whyte ET. Use of MIB-1 (Ki-67) immunoreactivity in differentiating grade II and grade III gliomas. J Neuropathol Exp Neurol 1997; 56(8): 857-65.

27. Karamitopoulou E, Perentes E, Diamantis I, Maraziotis T. Ki-67 immunoreactivity in human central nervous system tumors: a study with MIB 1 monoclonal antibody on archival material. Acta Neuropathol 1994; 87(1): 47-54.

28. Khalid H, Shibata S, Kishikawa M, Yasunaga A, Iseki M, Hiura T. Immunohistochemical analysis of progesterone receptor and $\mathrm{Ki}-67$ labeling index in astrocytic tumors. Cancer 1997; 80(11): 2133-40.

29. Reavey-Cantwell JF, Haroun RI, Zahurak M, et al. The prognostic value of tumor markers in patients with glioblastoma multiforme: analysis of 32 patients and review of the literature. J Neurooncol 2001; 55(3): 195-204.

30. Giangaspero F, Doglioni C, Rivano MT, Pileri $\mathrm{S}$, Gerdes J, Stein H. Growth fraction in human brain tumors defined by the monoclonal antibody Ki-67. Acta Neuropathol 1987; 74(2): 179-82.

31. Schiffer D, Cavalla P, Chio A, Richiardi P, Giordana MT. Proliferative activity and prognosis of low-grade astrocytomas. J Neurooncol 1997; 34(1): 31-5.

32. Torp SH, Alsaker M. Ki-67 immunoreactivity, basic fibroblastic growth factor (bFGF) expression, and microvessel density as supplementary prognostic tools in low-grade astrocytomas. An immunohistochemical study with special reference to the reliability of 
different Ki-67 antibodies. Pathol Res Pract 2002; 198(4): 261-5.

33. Wakimoto H, Aoyagi M, Nakayama T, et al. Prognostic significance of Ki-67 labeling indices obtained using MIB-1 monoclonal antibody in patients with supratentorial astrocytomas. Cancer 1996; 77(2): 373-80.

34. Deininger MH, Weller M, Streffer J, Mittelbronn M, Meyermann R. Patterns of cyclooxygenase-1 and -2 expression in human gliomas in vivo. Acta Neuropathol 1999; 98(3): 240-4.

35. Taketo MM. Cyclooxygenase-2 inhibitors in tumorigenesis (Part II). J Natl Cancer Inst 1998; 90(21): 1609-20.

36. Castelli MG, Chiabrando C, Fanelli R, et al. Prostaglandin and thromboxane synthesis by human intracranial tumors. Cancer Res 1989; 49(6): 1505-8.

37. Sung JJ, Leung WK, Go MY, et al. Cyclooxygenase-2 expression in Helicobacter pylori-associated premalignant and malignant gastric lesions. Am J Pathol 2000; 157(3): 72935 .

38. Okami J, Yamamoto H, Fujiwara Y, et al. Overexpression of cyclooxygenase-2 in carcinoma of the pancreas. Clin Cancer Res 1999; 5(8): 2018-24.

39. Yoshimura R, Sano H, Masuda C, et al. Expression of cyclooxygenase-2 in prostate carcinoma. Cancer 2000; 89(3): 589-96.

40. Buccoliero AM, Caldarella A, Arganini L, et al. Cyclooxygenase-2 in oligodendroglioma: possible prognostic significance. Neuropathology 2004; 24(3): 201-7.

41. Subbaramaiah K, Altorki N, Chung WJ, Mestre JR, Sampat A, Dannenberg AJ. Inhibition of cyclooxygenase-2 gene expression by $\mathrm{p} 53$. J Biol Chem 1999; 274(16): 10911-5.
42. Sato A, Mizobuchi Y, Nakajima K, et al. Blocking COX-2 induces apoptosis and inhibits cell proliferation via the Akt/survivin- and Akt/ID3 pathway in low-grade-glioma. J Neurooncol 2017; 132(2): 231-8.

43. Tsujii M, DuBois RN. Alterations in cellular adhesion and apoptosis in epithelial cells overexpressing prostaglandin endoperoxide synthase 2. Cell 1995; 83(3): 493-501

44. Enestrom S, Vavruch L, Franlund B, Nordenskjold B. Ki-67 antigen expression as a prognostic factor in primary and recurrent astrocytomas. Neurochirurgie 1998; 44(1): 25 30.

45. Ralte AM, Sharma MC, Karak AK, Mehta VS, Sarkar C. Clinicopathological features, MIB-1 labeling index and apoptotic index in recurrent astrocytic tumors. Pathol Oncol Res 2001; 7(4): 267-78.

46. Torp SH. Diagnostic and prognostic role of Ki67 immunostaining in human astrocytomas using four different antibodies. Clin Neuropathol 2002; 21(6): 252-7.

47. Di X, Nishizaki T, Harada K, Kajiwara K, Nakayama H, Ito H. Proliferative potentials of glioma cells and vascular components determined with monoclonal antibody MIB-1. J Exp Clin Cancer Res 1997; 16(2): 153-7.

48. Sallinen PK, Haapasalo HK, Visakorpi T, et al. Prognostication of astrocytoma patient survival by Ki-67 (MIB-1), PCNA, and S-phase fraction using archival paraffin-embedded samples. J Pathol 1994; 174(4): 275-82.

49. Prayson RA, Castilla EA, Vogelbaum MA, Barnett GH. Cyclooxygenase-2 (COX-2) expression by immunohistochemistry in glioblastoma multiforme. Ann Diagn Pathol 2002; 6(3): 148-53. 